\title{
Oversiktsartikkel
}

\section{Måling av kalprotektin i feces}

\author{
Sammendrag \\ Bakgrunn. Kalprotektin er et kalsium- \\ bindende protein som finnes i nøytrofile \\ granulocytter. Ved skade på tarmslim- \\ hinnen på grunn av inflammasjon vil \\ granulocyttene vandre ut i tarmlumen, \\ og forhøyede verdier av kalprotektin \\ kan måles i avføringen.
}

\section{Materiale og metode. Oversikten er basert på artikler funnet ved ikke-sys- tematiske søk i Medline og mer enn ti års klinisk erfaring med måling av kal- protektin i feces.}

Resultater. Kalprotektin er først og fremst en meget god markør for inflammasjon. Måling av kalprotektin i feces er derfor en nyttig undersøkelse $i$ utredningen av mageplager der det ut ifra symptomer og klinisk unders $\varnothing$ kelse er vanskelig å avgjøre om det dreier seg om en funksjonell eller organisk tilstand. På diagnosetidspunket vil alle pasienter med inflammatorisk tarmsykdom ha klart forhøyede verdier av kalprotektin i feces. Ved irritabel tarm-syndrom er verdiene normale. Normalisering av kalprotektinnivået i feces ved inflammatorisk tarmsykdom synes å være en sterk indikator på tilheling av tarmslimhinnen.

Fortolkning. Bestemmelse av kalprotektin i feces kan bidra til at pasienter ikke utsettes for unødvendige koloskopier. Dette er særlig viktig hos barn. Kalprotektinmåling i feces er en enkel og objektiv test til å vurdere behandlingsrespons og sykdomsforløp hos pasienter med inflammatorisk tarmsykdom.

\section{Jørgen Jahnsen}

jorgen.jahnsen@medisin.uio.no Avdeling for fordøyelsessykdommer Oslo universitetssykehus, Aker 0514 Oslo

\section{Arne G. Røseth}

Medisinsk avdeling

Lovisenberg diakonale sykehus

Oslo

\section{Erling Aadland}

Avdeling for fordøyelsessykdommer Oslo universitetssykehus, Aker

Kalprotektin er et lite protein som kan påvises i ulike kroppsvæsker og vev ved hjelp av ELISA-metodikk og immunhistokjemi. I hovedsak kommer dette proteinet fra nøytrofile granulocytter. Bestemmelse av kalprotektin i feces ble forsøkt markedsført i 1990-årene som en test for kolorektal kreft. Dette medførte imidlertid at denne testen kom i miskreditt, pga. for lav spesifisitet.

Internasjonalt har det de siste årene vært stor oppmerksomhet rundt kalprotektin, og bare det siste året er det publisert mer enn 50 arbeider der kalprotektin er undersøkt i feces eller i andre kroppsvæsker og vev.

I det følgende omtales måling av kalprotektin i feces ved diagnostikk og oppfølging av pasienter med inflammatorisk tarmsykdom og irritabel tarm-syndrom.

\section{Materiale og metode}

Denne oversiktsartikkelen er basert på ikkesystematisk litteratursøk i Medline samt egne kliniske erfaringer med kalprotektinmåling i feces i mer enn ti år.

\section{Kalprotektin i feces}

Etter at granulocyttene forlater beinmargen sirkulerer de fritt noen timer i blodbanen. Dernest tilbringer de noen dager i ulike perifere vev, før de fleste ender sitt liv i gastrointestinalkanalen (1). Her frigjør granulocyttene en rekke antimikrobielle substanser, blant annet kalprotektin. Det antas at kalprotektin har en viktig biologisk funksjon i regulering av tarmfloraen.

Tarmslimhinnen eksponeres kontinuerlig for enorme mengder mikroorganismer og deres toksiske produkter, blant annet kjemotaktiske substanser som endotoksiner. Dette er trolig forklaringen på at konsentrasjonen av kalprotektin i normalt tarminnhold er mange ganger høyere enn i blod. Kalprotektin ble først beskrevet av Magne Fagerhol og medarbeidere i 1980 (2). Det er omtrent 20 pg kalprotektin i hver granulocytt, og dette utgjør ca. $5 \%$ av den totale mengde protein og hele $60 \%$ av proteinet i cytosolfraksjonen i disse cellene. Til sammenlikning er det omtrent like mye kalprotektin i en granulocytt som hemoglobin i en rød blodcelle. Kalprotektin binder både kalsium og sink og har en rekke biologiske egenskaper. Som nevnt virker det antimikrobielt (3), det hemmer mange metalloproteinaser (4) og induserer apoptose i maligne og ikke-maligne cellekulturer (5). Proteinet frigjøres fra granulocyttene når disse aktiveres, og konsentrasjonen i blod og feces kan stige til over 100 ganger normalverdien, f.eks. ved aktiv revmatoid artritt (6), meningokokksepsis (M. Fagerhol, personlig meddelelse) og aktiv inflammatorisk tarmsykdom (7-9).

I nærvær av kalsium er proteinet stabilt og resistent mot enzymatisk nedbrytning, og det er påvist uendrede nivåer i fecesprøver etter oppbevaring i sju dager ved romtemperatur (7). Det betyr at legekontorer eller pasienter kan sende prøver direkte til laboratoriet med ordinær postgang.

En rekke undersøkelser i både Norge, England og USA viser at friske individer gjennomgående har kalprotektinverdier $\mathrm{i}$ feces under $50 \mathrm{mg} / \mathrm{kg}$ mens pasienter med aktiv inflammatorisk tarmsykdom, uansett lokalisasjon i gastrointestinalkanalen, ofte har konsentrasjoner over $500-1000 \mathrm{mg} / \mathrm{kg}$ (8-11). Pasienter med cøliaki har i likhet med friske individer normale kalprotektinverdier i feces (12).

Kalprotektinanalyser utføres ved flere sykehus i Norge (bl.a. Ullevål universitetssykehus, Universitetssykehuset Nord-Norge, Nordlandssykehuset i Bodø og Haukeland universitetssykehus) og ved Fürst laboratorium i Oslo. Det er også utviklet en kvantitativ hurtigtest som ventes om kort tid å være tilgjengelig til klinisk bruk (13).

\section{Hovedbudskap}

- Kalprotektin i feces er en god markør for inflammasjon i gastrointestinalkanalen

- Bestemmelse av kalprotektin i feces har stor verdi i differensialdiagnostisering mellom irritabel tarm-syndrom og inflammatorisk tarmsykdom

- Målingen kan benyttes til å vurdere sykdomsforløp og behandlingseffekt ved inflammatorisk tarmsykdom 


\section{Ramme 1}

\section{Roma III-kriteriene for diagnostikk av irritabel tarm-syndrom \\ Pasienten skal være plaget med residive- rende magesmerter eller ubehag i mer enn seks måneder. I tillegg skal plagene ha vært til stede minst tre dager per må- ned i tre måneder. Samtidig må minst to av følgende forhold være til stede: \\ - Plagene lindres i forbindelse med avfø- ring, og/eller \\ - forandring i avføringsfrekvens ved symptomdebut, og/eller \\ forandringer i avføringens konsistens ved symptomdebut}

\section{Irritabel tarm-syndrom}

Vedvarende mageplager er en vanlig grunn til konsultasjoner i allmennpraksis. Irritabel tarm-syndrom er den hyppigste årsaken og forekommer hos mellom $10-20 \%$ av den voksne befolkning $\mathrm{i}$ den vestlige verden (14). Det er angitt at ca. $40 \%$ av alle henvisninger til koloskopi skyldes irritabel tarmsyndrom (15). Lidelsen forekommer i alle aldersgrupper, også hos barn, men er vanligst $i$ alderen 20-40 år, med en viss overvekt blant kvinner. Diagnosen stilles ved hjelp av Roma III-kriteriene (ramme 1), men mange betrakter den som en eksklusjonsdiagnose, ved at organisk sykdom utelukkes. Symptomer på irritabel tarm-syndrom kan lett forveksles med ubehandlet cøliaki, laktoseintoleranse og ikke minst ulcerøs kolitt og Crohns sykdom. Leger med spesiell interesse for syndromet bestrider at omfattende undersøkelser er nødvendig for å stille diagnosen (16). Siden tilstanden er så vanlig, er kostnadene til undersøkelser som laboratorieprøver, endoskopi og bildediagnostikk meget store. Beregninger fra USA og Storbritannia viser at dette utgjør hele $0,5 \%$ av det totale helsebudsjettet. I tillegg kommer de indirekte kostnadene som fravær fra jobb og sykmeldinger (17). En enkel og pålitelig test til å skille organisk sykdom fra funksjonelle tilstander vil ha stor betydning. Særlig hos barn er det viktig å unngå invasive undersøkelser hvis mulig.

\section{Inflammatorisk tarmsykdom}

Flere studier har vist at kalprotektin i feces har høy sensitivitet for å påvise aktiv inflammatorisk tarmsykdom. Blodprøver som senkningsreaksjon (SR) og C-reaktivt protein (CRP) kan ofte være normale selv om det er betydelig inflammatorisk aktivitet $\mathrm{i}$ tarmslimhinnen (7, 9, 18-20). Det er ikke uvanlig at pasienter med inflammatorisk tarmsykdom også har symptomer på irritabel tarm-syndrom som kan være vanskelig eller helt umulig å skille fra symptomer som skyldes aktiv inflammasjon i tarmen. I denne situasjonen kan bestemmelse av kalprotektin i feces være til stor hjelp og i mange tilfeller erstatte koloskopi.

SR og CRP blir mye brukt som objektive parametere for sykdomsaktivitet ved inflammatorisk tarmsykdom, men nytteverdien synes å være relativt liten $(19,20)$. Det er utviklet flere kliniske indekser, men felles for disse er at de er basert på subjektive symptomangivelser og har vist seg lite reproduserbare for den enkelte pasient (21). Koloskopi er ofte nødvendig og gir mulighet for direkte inspeksjon av tarmslimhinnen i tillegg til at det kan tas biopsier. Ulempen er at undersøkelsen er invasiv og ubehagelig for den enkelte pasient. I en nylig publikasjon fra Sipponen og medarbeidere er det foreslått at fecesmarkører som kalprotektin og laktoferrin helt eller delvis kan erstatte koloskopi i oppfølgingen av Crohns sykdom (20). Kalprotektinverdien i feces korrelerer svært godt med utskillingen av isotopmerkede granulocytter $(r=0,87, p<0,0001)(22)$. Det er også en meget god korrelasjon mellom kalprotektinnivået i feces og inflammatorisk aktivitet bedømt med endoskopi og histologi $(8,23,24)$. Ved Aker universitetssykehus er det rutine at pasientene regelmessig sender in fecesprøver som ledd i oppfølgingen.

Inflammatorisk tarmsykdom er en kronisk tilstand med svingende sykdomsaktivitet. Ved klinisk tilbakefall kan det være viktig med rask intensivering av behandlingen.
I en prospektiv studie viste Tibble og medarbeidere at kalprotektin kan brukes til å forutsi risikoen for fremtidig oppbluss av sykdommen. Blant pasienter i klinisk remisjon og kalprotektinverdier i feces over $250 \mathrm{mg} /$ $\mathrm{kg}$ fikk $85 \%$ et tilbakefall i løpet av de neste 12 måneder i motsetning til pasienter med verdier under $250 \mathrm{mg} / \mathrm{kg}$, hvor kun $12 \%$ fikk tilbakefall i det samme tidsrommet (25). Liknende resultater er også publisert fra en italiensk undersøkelse (10). I overensstemmelse med dette fant man at pasienter med lavgradig infiltrasjon av betennelsesceller $\mathrm{i}$ tarmslimhinnen hadde størst risiko for fremtidig tilbakefall (26). CRP hadde ingen prediktiv verdi i disse studiene.

I en studie fra Aker universitetsykehus fant vi at normalisering av kalprotektinnivået hos pasienter med inflammatorisk tarmsykdom var en sterk indikator for tilheling av slimhinnen (27). 45 pasienter med inflammatorisk tarmsykdom og normal kalprotektinverdi i feces $(<50 \mathrm{mg} / \mathrm{kg})$ ble undersøkt med koloskopi. Av disse hadde 44 normal slimhinne bedømt endoskopisk, og helt normal histologi ble påvist hos 38 pasienter. Sju pasienter hadde kun lett infiltrasjon av leukocytter, men uten affeksjon av slimhinnen eller kryptene. Normalisering av avslimhinnen er et viktig mål $i$ behandlingen av inflammatorisk tarmsykdom fordi det medfører lavere forekomst av tilbakefall, færre innleggelser i sykehus og redusert risiko for komplikasjoner og kirurgiske inngrep (28-30).

\section{Praktisk bruk av kalprotektinmåling}

Sensitivitet, spesifisitet, positivt og negativt prediktiv verdi for kalprotektin i feces til å skille forskjellige organiske og funksjonelle tilstander i gastrointestinalkanalen varierer i ulike studier (tab 1) $(10,11,18,31,32)$. Dette skyldes i hovedsak forskjeller i utvelgelsen av pasienter både når det gjelder alder, kjent diagnose, symptomatologi, sykdomsutbredning og inflammatorisk aktivitet. I en av studiene med lav sensitivitet fikk en tredel av pasientene med organisk årsak til diaré og normal verdi av kalprotektin i feces diagnosen cøliaki (31). I en metanalyse som

Tabell 1 Diagnostisk presisjon for kalprotektin i feces til å skille mellom ulike kliniske tilstander ved forskjellige grenseverdier

\begin{tabular}{|c|c|c|c|c|c|c|}
\hline & Pasienter (n) & $\begin{array}{c}\text { Sensitivitet } \\
(\%)\end{array}$ & $\begin{array}{l}\text { Spesifisitet } \\
(\%)\end{array}$ & $\begin{array}{c}\text { Positiv } \\
\text { prediktiv } \\
\text { verdi }(\%)\end{array}$ & $\begin{array}{l}\text { Negativ } \\
\text { prediktiv } \\
\text { verdi }(\%)\end{array}$ & Referanse \\
\hline Organisk årsak ved kronisk diaré. Grenseverdi 50 g/g & 120 & 66 & 84 & 83 & 68 & Carroccio (31) \\
\hline Organisk årsak ved kronisk diaré. Grenseverdi 100 g/g & 120 & 46 & 93 & 90 & 59 & Carroccio (31) \\
\hline $\begin{array}{l}\text { Organiske versus funksjonelle tilstander i gastrointes- } \\
\text { tinalkanalen. Grenseverdi } 50 \mu \mathrm{g} / \mathrm{g}\end{array}$ & 239 & 83 & 82 & 90 & 71 & Costa (10) \\
\hline $\begin{array}{l}\text { Crohns sykdom versus irritabel tarm-syndrom. Grense- } \\
\text { verdi } 150 \mu \mathrm{g} / \mathrm{g}\end{array}$ & 190 & 100 & 97 & 89 & 100 & Tibble (18) \\
\hline $\begin{array}{l}\text { Kolorektal inflammasjon ved kronisk diaré. Grenseverdi } \\
100 \mu \mathrm{g} / \mathrm{g}\end{array}$ & 110 & 83 & 95 & 63 & 94 & Limburg (11) \\
\hline $\begin{array}{l}\text { Kolorektal inflammasjon ved gastrointestinale sympto- } \\
\text { mer. Grenseverdi } 50 \mu \mathrm{g} / \mathrm{g}\end{array}$ & 36 & 95 & 93 & 95 & 93 & Fagerberg (32) \\
\hline
\end{tabular}


omfatter 13 studier og 1595 pasienter, fant man at kalprotektin i feces er 89-98\% sensitiv og 81-91\% spesifikk til å skille inflammatorisk tarmsykdom fra funksjonelle tilstander (33).

Valg av grenseverdi har også betydning. Tibble og medarbeidere har vist at den optimale grenseverdien for å skille mellom irritabel tarm-syndrom og inflammatorisk tarmsykdom er $150 \mathrm{mg} / \mathrm{kg}$ (18). Egne og finske erfaringer tilsier at lett forhøyede verdier (50-200 mg/kg) bør kontrolleres med en ny prøve før man bestemmer om det er nødvendig med videre utredning med koloskopi, dersom det ikke foreligger alarmsymptomer som blødning og vekttap (20).

Ettersom negativ prediktiv verdi ved normalt nivå av kalprotektin i feces hos pasienter med mageplager er nær $100 \%$ ved aktiv inflammatorisk tarmsykdom, kan riktig bruk av testen resultere $\mathrm{i}$ en reduksjon av antall koloskopier. Det er viktig å unngå unødvendige koloskopier, fordi dette er en ressurskrevende og invasiv undersøkelse med potensielle komplikasjoner og medfører ofte ubehag for pasienten. Pasienter med symptomer forenlig med irritabel tarm-syndrom og normal verdi av kalprotektin i feces har etter vår erfaring normale koloskopifunn. På King's College i London som har brukt testen i mange år, har man beregnet en innsparing på 600000 euro per overlege per år i unødvendige endoskopier og bildediagnostikk (Ingvar Bjarnason, personlig meddelelse).

Ved Aker universitetssykehus har måling av kalprotektin i feces i mange år blitt brukt rutinemessig ved oppfølging av pasienter med inflammatorisk tarmsykdom.

\section{Konklusjon}

Kalprotektin i feces er et objektivt kriterium for inflammasjon og sykdomsaktivitet ved inflammatorisk tarmsykdom og velegnet til å vurdere sykdomsforløp og monitorere behandlingseffekt hos disse pasientene. Irritabel tarm-syndrom er en kronisk lidelse og hyppig årsak til konsultasjon både hos allmennlege og spesialist. Denne pasientgruppen har normal verdi av kalprotektin i feces. Et økende antall personer blir henvist til koloskopi. Ved riktig bruk av kalprotektinmålinger $\mathrm{i}$ feces tror vi at mange av disse koloskopiene kan unngås.

Oppgitte interessekonflikter: Jørgen Jahnsen og Erling Aadland har ingen oppgitte interessekonflikter. Arne G. Røseth har patentrettigheter i enkelte land med hensyn til kommersiell bruk av kalprotektin i feces.

Litteratur
1. Fliedner SH, Cronkite EP, Robertson JS. Granulopoesis, senescence and random loss of neutrophilic granulocytes in human beings. Blood 1964; 24 : 404-14.

2. Fagerhol MK, Dale I, Andersson T. Release and quantification of a leucocyte derived protein (L1). Scand J Haematol 1980; 24: 393-8.
3. Steinbakk M, Naess-Andresen CF, Lingaas E et al. Antimicrobial action of a calcium binding leukocyte L-1 protein, calprotectin. Lancet 1990; 336 : $763-5$.

4. Isaksen B, Fagerhol MK. Calprotectin inhibits matrix metalloproteinases by sequestrion of zink. Mol Pathol 2001; 54: 289-92.

5. Yui S, Mikami M, Yamazaki M. Induction of apoptotic cell death in mouse lymphoma and human leukemia cell lines by a calcium-binding complex, calprotectin, derived from inflammatory peritoneal exudate cells. J Leukoc Biol 1995; 58: $650-8$.

6. Berntzen HB, Olmez U, Fagerhol MK et al. The leukocyte protein L1 in plasma and synovial fluid from patients with rheumatoid arthritis and osteoarthritis. Scand J Rheumatol 1991; 20 : $74-82$

7. Røseth AG, Fagerhol MK, Aadland E et al. Assessment of the neutrophil dominating protein calprotectin in feces. Scand J Gastroenterol 1992; 27 793-8.

8. Bunn SK, Bisset WM, Main MJC et al. Faecal calprotectin: Validation as a noninvasive measure of bowel inflammation in childhood inflammatory bowel disease. J Pediatr Gastroenterol Nutr 2001 33: $14-22$.

9. Fagerberg UL, Lööf $L$, Lindholm J et al. Fecal calprotectin: A quantitative marker of colonic inflammation in children with inflammatory bowel disease. J Pediatr Gastroenterol Nutr 2007; 45: 414-20.

10. Costa F. Mumolo MG, Bellini M al. Role of faecal calprotectin as non-invasive marker of intestinal inflammation. Dig Liver Dis 2003; 35: 642-7.

11. Limburg PJ, Ahlquist DA, Sandborn WJ et al. Fecal calprotectin levels predict colorectal inflammation among patients with chronic diarrhea referred for colonoscopy. Am J Gastroenterol 2000; 95 : $2831-7$

12. Montalto M, Santoro L, Curgliano V et al. Faecal calprotectin concentrations in untreated celiac patients. Scand J Gastroenterol 2007; 42: 957-61.

13. Roseth A, Fagerhol MK, Wasiluk J et al. A new «calprotectin PoC device» correlates with ELISA and separates between endoscopic assessed mucosal healing and active ulcerative colitis. Gastroenterology Suppl 2007; 132: A175.

14. Drossman DA, Camilleri M, Mayer EA. AGA technical review on irritable bowel syndrome. Gastroenterology 2002; 123: 2108-31.

15. Suleiman S, Sonnenberg A. Cost-effectiveness of ndoscopy in irritable bowel syndrome. Arch Intern Med 2001; 161: 369-75.

16. Longstreth GF, Thompson WG, Chey WD et al. Functional bowel disorders. Gastroenterology 2006; 130: 1480-91.

17. Camilleri M, Williams DE. Economic burden of irritable bowel syndrome. Proposed strategies to control expenditures. Pharmacoeconomics 2000; 17: $331-8$.

18. Tibble J, Teahon K, Thjodleifsson B et al. A simple method for assessing intestinal inflammation in Crohn's disease. Gut 2000; 47: 506-13.

19. Vermeeire S, van Assche G, Rutgeerts P. Laboratory markers in IBD; useful, magic, or unnecessary toys? Gut 2006; 55: 426-31.

20. Sipponen T, Savilathi E, Kolho KL et al. Crohn's disease activity assessed by fecal calprotectin and lactoferrin: Correlation with Crohn's disease activity index and endoscopic findings. Inflamm Bowel Dis 2007; 13: $1-7$

21. D'Haens G, Sandborn WJ, Feagan BG et al. A review of activity indices and efficacy end points for clinical trial of medical therapy in adults with ulcerative colitis. Gastroenterology 2007; 132: 763-86.

22. Roseth AG, Schmidt PN, Fagerhol MK. Correlation between faecal excretion of indium-111-labelled granulocytes and calprotectin, a granulocyte marker protein in patients with inflammatory bowel disease. Scand J Gastroenterol 1999; 34: $50-4$

23. Roseth AG, Aadland E, Jahnsen J et al. Assessment of disease activity in ulcerative colitis by faecal calprotectin, a novel granulocyte marker protein. Digestion 1997; 58: 176-80.

24. D'Haens G. Baert F. Vermeire S et al. Mucosal inflammation in inflammatory bowel disease can reliably be predicted with the fecal calprotectin test. Gastroenterology 2007; 132: A 174.
25. Tibble JA, Sigthorsson G, Bridger S et al. Surrogate markers of intestinal inflammation are predictive of relapse in patients with inflammatory bowel disease. Gastroenterology 2000; 119: 15-22.

26. Bitton A, Peppercorn MA, Antonioli DA. Clinical, biological and histological parameters as predictors of relapse in ulcerative colitis. Gastroenterology 2001; 120: 13-20.

27. Røseth AG. Aadland E, Grzyb K. Normalization of faecal calprotectin: a predictor of mucosal healing in patients with inflammatory bowel disease. Scand J Gastroenterol 2004; 39: 1017-20.

28. D'Haens G, Noman B, Rutgeerts P. Endoscopic healing after Infliximab treatment for Crohn's disease provides a longer time to relapse. Abstrakt. Gastroenterology 2002; 122: A100.

29. Frøslie KF, Jahnsen J, Moum BA et al. Mucosal healing in inflammatory bowel disease: results from a Norwegian population-based cohort. Gastroenterology 2007; 133: 412-22.

30. Rutgeerts P. Diamond RH, Bala M et al. Scheduled maintenance treatment with infliximab is superior to episodic treatment for the healing of mucosal ulceration associated with Crohn's disease. Gastrointest Endosc 2006; 63: 433-42.

31. Carroccio A, lacono G, Cottone M et al. Diagnostic accuracy of fecal calprotectin assay in distinguishing organic causes of chronic diarrhea from irritable bowel syndrome: a prospective study in adults and children. Clin Chem 2003; 49: 861-7.

32. Fagerberg UL, Lööf L, Myrdal U et al. Colorectal inflammation is well predicted by fecal calprotectin in children with gastrointestinal symptoms. J Pediatr Gastroenterol Nutr 2005; 40: 450-5.

33. von Roon AC, Karamountzos L, Purkayastha $S$ et al. Diagnostic precision of fecal calprotectin for inflammatory bowel disease and colorectal malignancy. Am J Gastroenterol 2007; 102: 803-13.

Manuskriptet ble mottatt 28.6. 2008 og godkjent 3.1. 2009. Medisinsk redaktør Michael Bretthauer. 